NBER WORKING PAPER SERIES

INTERNATIONAL CAPITAL MOBILITY AND TAX EVASION

Alberto Giovannini

Working Paper No. 2460

NATIONAL BUREAU OF ECONOMIC RESEARCH

1050 Massachusetts Avenue

Cambridge, MA 02138

December 1987

This paper is part of a project on "Capital Controls and Liberalization: Costs and Benefits," financed by a World Bank McNamara Fellowship. I am grateful to Michael Gavin, Pentti Kouri, Michael Salinger and seminar participants at the National Bureau of Economic Research and Columbia University for suggestions, and to Carmen Reinhart for assistance. The research reported here is part of the NBER's research program in International Studies. Any opinions expressed are those of the author and not those of the National Bureau of Economic Research. Support from the 01 in Foundation is gratefully ackrowledged. 
NBER WORKING PAPER SERIES

INTERNATIONAL CAPITAL MOBILITY AND TAX EVASION

Alberto Giovannini

Working Paper No. 2460

NATIONAL BUREAU OF ECONOMIC RESEARCH 1050 Massachusetts Avenue Cambridge, MA 02138

December 1987

This paper is part of a project on "Capital Controls and Liberalization: Costs and Benefits," financed by a World Bank McNamara Fellowship. I am grateful to Michael Gavin, Pentti Kouri, Michael Salinger and seminar participants at the National Bureau of Economic Research and Columbia University for suggestions, and to Carmen Reinhart for assistance. The research reported here is part of the NBER's research program in International Studies. Any opinions expressed are those of the author and not those of the National Bureau of Economic Research. Support from the 01 in Foundation is gratefully arknowledged. 
NBER Working Paper \#2460

December 1987

\section{International Capital Mobility and Tax Evasion}

\section{ABSTRACT}

This paper studies the welfare effects of international investment to evade domestic taxes on domestic investment income. Capital mobility for tax evasion eliminates distortions in the intertemporal allocation of consumption, but introduces distortions in domestic production. Conversely, a regime where residents pay taxes on all investment income, domestic and foreign, introduces distortions in intertemporal consumption allocation, but leaves domestic production distortion-free. The relative magnitude of the interest elasticity of savings and the interest elasticity of domestic investment determines the welfare effects of capital movements for the purpose tax evasion.

Alberto Giovannini NBER 1050 Massachusetts Avenue Cambridge, MA 02138 


\section{Introduction}

In an open economy, foreign investment is often used as a means of evading taxes on wealth, or on capital assets' income. The purchase of foreign assets makes it easy to evade taxes for three reasons: (a) ownership of foreign assets by domestic residents cannot always be verified and tracked by tax authorities; (b) some governments (like the US government currently) do not levy withholding taxes on income from domestic securities accruing to foreign residents; (c) in many countries it is possible to defer the payment of taxes on foreign assets' income, by deferring the repatriation of such income. The complexity of national tax codes, and the differences of tax codes from country to country, in many cases blur the distinction between (illegal) tax evasion, and (legal) tax avoidance, and multiply the opportunities of the private sector to minimize tax payments through international transactions. ${ }^{1}$

This paper presents the simple analytics of tax evasion through international capital mobility. It discusses the general-equilibrium effects of tax evasion and evaluates its impact on domestic welfare, under the assumption that the distortionary taxes on capital income cannot be removed.

International capital mobility and the constraints it imposes on macroeconomic policies are the central issues of theoretical and empirical

1 In this paper I use the term "evasion" to denote all transactions motivated by the desire to minimize tax payments. Given the current state of international tax laws, many such transactions are in fact legal. This paper is not concerned with the resource cost of breaking the law, and the resources used to enforce the law. For the purpose of my analysis, the distinction between tax avoidance and tax evasion is inconsequential. 
research in international economics. ${ }^{2}$ Surprisingly, however, few papers have analyzed the repercussions of changes in taxes on international capital flows, and, as a consequence, on the domestic economy. Among the recent examples, Aizenman [1985] studies the optimal combination of the inflation tax, capital controls, and tariffs, for the purpose of raising a given amount of government revenue, in an economy without production; ${ }^{3}$ Stockman and Hernadez [1985] discuss taxes on the purchase of foreign currency in a general-equilibrium asset pricing model, while Gordon and Varian [1986] consider the optimal structure of capital-asset taxes in an international capital asset pricing model; Frenkel and Razin [1987] analyze the effects of tax reforms on international borrowing and lending in a two-country world; Tornel1 [1987] and Velasco [1987] argue that capital controls might be desirable as second-best devices in the presence of distortionary taxation.

International capital flows to evade domestic wealth and capital-income taxes are likely to be a widespread phenomenon, especially among developing countries. ${ }^{4}$ Tanzi [1983], reviewing the structure of tax revenues in developing countries, notes that (i) income tax revenue is accounted for almost exclusively by taxation of wages; (ii) in poor countries the revenue from corporate income taxes is very low; (iii) wealth taxes account for an almost insignificant

2 For a recent survey on international capital mobility, see obstfeld [1986].

3 Extending the optimal tariff 1iterature to account for international capital mobility, Kemp [1966] and Jones [1967] study the optimal combination of tariffs and taxes on international investment.

4 See, for example, Walter [1986]. 


\section{The Model}

I consider a one-good, two-period model of an open economy. ${ }^{6}$ Domestic residents consume in period 1 and period 2 , and can transfer wealth intertemporally by investing in domestic capital or by purchasing (or selling) foreign bonds. The government taxes only income from domestic investments. Tax revenues are used to finance "infrastructures" that provide a positive externality to domestic residents. The government does not spend in the first period: thus there is no government debt. Taxes, however, are known by domestic residents at the time investment decisions are made.

I study a small country, and assume that the foreign interest rate is given. This case is both a useful theoretical benchmark, since it helps to highlight all the basic effects that are at work also in a two-country world, and a reasonable empirical paradigm, since in many countries the size of international capital flows is too small to affect the world rate of interest. Foreign residents can lend resources to domestic residents, but do not have direct access to the domestic technology. Any taxes paid to the local government, on income from loans to domestic residents, are instantaneously rebated through international tax treaties. These assumptions imply that domestic residents can borrow from the rest of the world at a given rate of interest, which I take to equal the world lending rate.

The consumers' problem is:

6 This model is also used by Obstfeld [1987]. Bhagwati [1978] stresses the importance of the effects of taxation and exchange controls on savings for welfare analysis. 
fraction of total tax revenue. These facts'are in principle consistent with the view that international capital mobility imposes severe constraints on fiscal authorities. Dornbusch [1987] argues that the repeal of withholding taxes on US government securities might have been an important determinant of capital flight from Latin American countries. Giovannini [1987], discussing the interwar experience in Italy, indicates that, during those years, international capital flows to evade wealth taxes were possibly very large. 5

Section 2 of this paper presents a two-period model of savings, investment, and the current account, where government spending can be financed only by levying distortionary taxes. The welfare effects of international investment for tax evasion are discussed in section 3. Section 4 endogenizes government spending, showing the open-economy effects of dynamic inconsistency and "discretionary" equilibria studied by Fischer [1980] and Kydland and Prescott [1980] in closed-economy models. Section 5 contains some concluding remarks. An appendix proves the equivalence between quantitative controls on international investment and a regime of uniform taxation of income from domestic and foreign assets.

5 Although, to my knowledge, there is no systematic econometric evidence relating international capital flight to tax evasion and changes in tax rates, there is a substantial literature attempting to quantifying tax evasion in the US. See Poterba [1987] for a review and tests relating capital-gains tax evasion to capital-gains tax rates. 


$$
\begin{array}{ll}
\operatorname{MAX} & \mathrm{U}\left(\mathrm{C}_{1}, C_{2}\right)+\mathrm{v}(\mathrm{G}) \\
\text { s.t. } & \mathrm{K}_{2}+\mathrm{C}_{1}+\mathrm{A}=\mathrm{K} \\
& \mathrm{C}_{2}=\mathrm{A}\left(1+\mathrm{r}^{*}\right)+\mathrm{f}\left(\mathrm{K}_{2}\right)(1-\tau)
\end{array}
$$

Where $C_{1}$ and $C_{2}$ stand for consumption in the two periods; $G$ is government spending; A represents the stock of foreign assets accumulated in period 1, i.e. the current account surplus in period $1 ; \mathrm{K}_{2}$ is the stock of productive capital in period 2, which equals the rate of investment in period 1 , and $K$ is the exogenous initial allocation of resources. $f\left(\mathrm{~K}_{2}\right)$ is a decreasing-returns-toscale production technology, yielding output in period 2. In the production process, the capital stock depreciates completely. $\tau$ is the tax rate; $r^{*}$ the world interest rate. In this section and in section 3 I analyze the effects of tax evasion by assuming that $\tau$--or G--is exogenously given. As equations (1)(3) suggest, the government could clearly optimize tax collection and spending: in section 4 I study equilibria in the presence of a maximizing government.

Equations (4)-(5) and (2)-(3) are the first order conditions for the consumption-savings and portfolio-allocation problem of the consumer:

$$
\begin{aligned}
& \mathrm{f}^{\prime}\left(\mathrm{K}_{2}\right)(1-\tau)=1+\mathrm{r}^{*} \\
& \mathrm{U}_{1}\left(\mathrm{C}_{1}, \mathrm{C}_{2}\right)=\left(1+\mathrm{r}^{*}\right) \mathrm{U}_{2}\left(\mathrm{C}_{1}, \mathrm{C}_{2}\right)
\end{aligned}
$$

Equation (4) determines domestic investment: the domestic capital stock is such that its after-tax marginal productivity equals the world interest factor, $1+r^{*}$. This portfolio allocation rule insures that the net return on savings is always equal to the world interest rate. Equation (5) is the standard Euler equation, 
setting the marginal rate of substitution between present and future consumption equal to the marginal rate of transformation, $1+r^{*}$. Given domestic investment, equation (5), together with (2) and (3), determine consumption, savings and the current account.

Figure 1 shows the determination of equilibrium with $\tau=0$. The bowed-out production-possibility frontier characterizes the domestic technology. Maximum consumption at time 1 equals the stock of available resources, $K$, plus the present discounted value (at the world rate of interest) of future investment income. The investment in domestic capital is determined by the equality of the marginal return on domestic and on foreign investment, i.e. the tangency of the production possibility frontier with the world intertemporal terms of trade--the BB line with slope $-\left(1+r^{*}\right)$. Savings, the current account, and consumption in the two periods are determined by the tangency of the consumption indifference curve and the $\mathrm{BB}$ line.

Figure 2 illustrates the effects of distortionary taxes in the presence of tax evasion. Equalization of the after-tax return on domestic investment with the world interest rate decreases the domestic capital stock and domestic production: the fall in $K_{2}$ is caused by tax evasion, which takes place because domestic residents can substitute home capital with foreign securities. The production distortion originating from the tax, however, does not affect the marginal rate of substitution between present and future consumption, since the fall in domestic investment insures that the net return on savings is $r^{*}$. The budget line shifts further down and to the left, from $B^{\prime} B^{\prime}$ to $B^{\prime \prime} B^{\prime \prime}$, since tax revenue is not rebated in a lump sum fashion to consumers, but is used to provide for utility-generating "infrastructures." At the consumption point $\mathrm{c}^{\prime}$, 
the vertical distance between the lines $B^{\prime} B^{\prime}$ and $B^{\prime \prime} B^{\prime \prime}$ is equal to tax revenue and government spending. Consumption at time 2 is accordingly decreased, for every level of investment. What is the effect of the distortionary tax on savings? If present and future consumption are normal goods, an increase in $r$ increases savings, whereas savings decreases if future consumption is an inferior good. Since portfolio substitution insures that the rate of return on savings is unchanged, savings is here affected exclusively by the income effect of the tax increase.

The effects of tax evasion can be evaluated by studying the case where residents cannot evade domestic taxes by purchasing foreign securities: income from all assets, domestic and foreign, is taxed at the same rate. When tax evasion is not possible, the intertemporal budget constraint has to be changed. Equation (3) becomes:

$$
C_{2}-(1-\tau)\left[A\left(1+r^{*}\right)+f\left(K_{2}\right)\right]
$$

Equation ( $\left.3^{\prime}\right)$ implies that domestic residents can deduct foreign interest payments--when $A$ is negative--from taxable income. The first-order condition for the consumption and portfolio-allocation problem are:

$$
\begin{gathered}
\mathrm{f}^{\prime}\left(\mathrm{K}_{2}\right)=1+\mathrm{r}^{*} \\
\mathrm{U}_{1}\left(\mathrm{C}_{1}, \mathrm{C}_{2}\right)=\left(1+\mathrm{r}^{*}\right)(1-\tau) \mathrm{U}_{2}\left(\mathrm{C}_{1}, \mathrm{C}_{2}\right)
\end{gathered}
$$

Figure 3 illustrates the effects of the tax distortions in this case. Investment and the domestic capital stock are now unaffected by changes in $r$. 
Thus international capital mobility now prevents capital income taxes from distoring the production side of the economy. ${ }^{7}$ By contrast, as indicated by (5'), the relevant rate of interest for savings is now the after-tax world interest rate.

The $B B^{\prime \prime}$ line shows the consumption possibilities of domestic residents. At point B, first-period consumption equals the sum of the present discounted value (at world interest rates) of second-period output and the initial endowment $k$, second-period consumption equals zero, the revenue from taxation of domestic production identically offsets the tax rebates on foreign interest payments, and government spending is zero. The vertical distance between the $\mathrm{BB}$ " 1 ine and the production point $P$ is the revenue from taxation of domestic production.

Equilibrium consumption, government spending, and the structure of tax revenues can be easily characterized as indicated in the figure. Line B'B' shows the consumption possibilities of domestic residents before taxation of foreign assets' income. The vertical distance between $B B$ and $B^{\prime} B^{\prime}$ is the revenue from the tax on domestic income, while the distance between $B B^{\prime \prime}$ and $B^{\prime} B^{\prime}$ is the revenue (or outlay) from foreign interest income (or payments). What is the response of savings to an increase in taxes? In the absence of tax evasion, intertemporal substitutability in consumption tends to decrease savings, while the income effect--if both periods' consumption levels are normal goods-increases savings. Thus the response of savings to an increase in the tax rate is ambiguous, because of conflicting income and substitution effects, just like

7 Notice that this would not happen in a closed economy, see, for example, Diamond [1970]. 
in the standard partial-equilibrium exercise.

\section{The Welfare Effects of Capital Flows for Tax Evasion}

A comparison of two regimes described in section 2. allows to determine whether tax evasion through international capital mobility lowers national welfare. The literature on optimal taxation provides the framework for the comparison. $^{8}$ The problem studied by the optimal taxation literature is finding the structure of taxes that minimizes the deviation (in terms of welfare) from the nondistorted, pre-tax equilibrium. ${ }^{9}$ The general prescription is to tax those goods with a smaller demand elasticity: this criterion insures that the after-tax allocation of resources is closest to the pre-tax, nondistorted optimum.

To carry out the welfare comparison of the two regimes, it is convenient to assume that both taxes on savings and capital income are available. The budget constraint can be rewritten after solving out the current account in the first period:

8 For surveys of the optimal taxation literature, see Sandmo [1976], and Atkinson and Stiglitz [1980]. Horst [1980] and Findlay [1986] use the same techniques to evaluate double taxation of international income flows and the optimal structure of international tax treaties.

9

The same question can be asked with the model in this paper, since the utility function is assumed to be separable in consumption and government spending. 


$$
c_{1}+\frac{C_{2}}{\left(1-\tau_{2}\right)\left(1+r^{*}\right)}=K+\frac{\left(1-\tau_{1}-\tau_{2}\right) f\left(K_{2}\right)}{\left(1-\tau_{2}\right)\left(1+r^{*}\right)}-K_{2}
$$

The tax rate on income from domestic investment is $\tau_{1}$, while the savings tax rate is $\tau_{2}$. Equation (6) comprises the two extreme cases studied above. In the presence of tax evasion, $\tau_{2}=0$ and $\tau_{1} \neq 0$. With uniform taxation, $\tau_{1}=0$ and $\tau_{2} \neq 0$. As above, the required rate of return on domestic investment is determined by the international arbitrage condition:

$$
f^{\prime}\left(K_{2}\right)\left(1-\tau_{1}-\tau_{2}\right)=\left(1+r^{*}\right)\left(1-\tau_{2}\right)
$$

Maximization of (1), subject to (6) and (7), leads to the following indirect utility function:

$$
W\left(\left(1-\tau_{2}\right)\left(1+r^{*}\right), K+Y\right)
$$

where $\mathrm{Y}$ is the net present value of domestic investment projects-i.e. the last two terms on the right-hand side of equation (6)--a function of $\tau_{1}, \tau_{2}$ and $r^{*}$. An application of the envelope theorem shows:

$$
\mathrm{dY} / \mathrm{d} \tau_{1}=-\left[\left(1-\tau_{2}\right)\left(1+\mathrm{r}^{*}\right)\right]^{-1}, \quad \mathrm{dY} / \mathrm{d} \tau_{2}=-\tau_{1} /\left[\left(1+\mathrm{r}^{*}\right)\left(1-\tau_{2}\right)^{2}\right]
$$

Since $G$ is exogenous, the welfare effects of tax evasion can be analyzed by minimizing the welfare loss of raising a given tax revenue. The problem is 
formally stated as follows:

$$
\begin{aligned}
& \operatorname{MAX} W\left(\left(1-\tau_{2}\right)\left(1+\mathrm{r}^{*}\right), \mathrm{K}+\mathrm{Y}\right) \\
& \text { s.t. } \tau_{2}\left[\mathrm{~A}\left(1+\mathrm{r}^{*}\right)+\mathrm{f}\left(\mathrm{K}_{2}\right)\right]+\tau_{1} \mathrm{f}\left(\mathrm{K}_{2}\right)=\mathrm{G}
\end{aligned}
$$

(10)-(11) can be solved using (7) and (9). The first order conditions are:

$$
\begin{array}{r}
\mathrm{W}_{1}+\frac{\mathrm{W}_{2} \tau_{1}}{\left(1-\tau_{2}\right)^{2}\left(1+\mathrm{r}^{*}\right)}=\lambda\left[\mathrm{A}\left(1+\mathrm{r}^{*}\right)+\mathrm{f}\left(\mathrm{K}_{2}\right)+\tau_{2}\left[\left(1+\mathrm{r}^{*}\right) \frac{\mathrm{dA}}{\mathrm{d} \tau_{2}}+\frac{\mathrm{df}\left(\mathrm{K}_{2}\right)}{\mathrm{d} \tau_{2}}\right]\right. \\
\left.+\tau_{1} \frac{\mathrm{df}\left(\mathrm{K}_{2}\right)}{\mathrm{d} \tau_{2}}\right] \\
\frac{\mathrm{W}_{1}}{\left(1-\tau_{2}\right)\left(1+\mathrm{r}^{*}\right)}=\lambda\left[\tau_{2}\left[\left(1+\mathrm{r}^{*}\right) \frac{\mathrm{dA}}{\mathrm{d} \tau}+\frac{\mathrm{df}\left(\mathrm{K}_{2}\right)}{\mathrm{d} \tau_{1}}\right]+\mathrm{f}\left(\mathrm{K}_{2}\right)+\tau_{1} \frac{\mathrm{df}\left(\mathrm{K}_{2}\right)}{\mathrm{d} \tau_{1}}\right]
\end{array}
$$

And equation (11). $W_{1}$ and $W_{2}$ are the partial derivatives of the $W$ function with respect to its first and second argument, respectively. $\lambda$ is the Lagrange multiplier associated with the revenue constraint (11).

Equations (12) and (13) do not have a closed-form solution, even assuming special functional forms for $W$ and $f$. Furthermore, the optimal $\tau_{1}$ and $\tau_{2}$ are normally both different from zero, i.e. neither of the regimes studied above is optimal according to the criterion just outlined. However, the immediate implication of the optimal-tax solution is that tax evasion is welfare-inferior when the optimal level of $\tau_{1}$ is much smaller than optimal $\tau_{2}$.

The structure of the problem, and in particular the determinants of tax revenue, provide some intuition for the conditions that make $\tau_{1}=0$ and $\tau_{2} \neq 0$ 
(no tax evasion) preferable to $\tau_{1} \neq 0$ and $\tau_{2}=0$ (the tax evasion case). The left hand side of equations (12) and (13) are affected by the parameters of the indirect utility function. Notice that the larger the intertemporal substitution elasticity, the larger the (positive) effect of an increase in the after-tax world interest rate on indirect utility (the larger is $W_{1}$ ), and consequently the smaller the optimal level of the savings tax. The right-hand side of (12) and (13) are affected by the marginal tax revenue. In the presence of tax evasion, an increase in taxes generates a fall in the domestic capital stock that is larger, the closer the production technology is to constant returns to scale. Differentiating equation (7) when $\tau_{1} \neq 0$ and $\tau_{2}=0$, we obtain:

$$
\frac{\mathrm{dK}_{2}}{\mathrm{~d} \tau_{1}}=\frac{\mathrm{f}^{\prime}\left(\mathrm{K}_{2}\right)}{\left(1-\tau_{1}\right) \mathrm{f}^{\prime \prime}\left(\mathrm{K}_{2}\right)}
$$

The closer the production technology to constant returns the smaller (in absolute value) the denominator on the right-hand side of (14), and therefore the larger the fall in the domestic capital stock after an increase in taxes. The elasticity of returns to scale of the domestic investment technology determines, in this open economy, the interest elasticity of domestic inves tment.

In the presence of tax evasion, an increase in $\tau$ brings about a fall of domestic investment, and of second-period GDP, that is positively related to the elasticity of returns to scale of the domestic investment technology. In a regime of uniform taxation $\left(\tau_{1}=0\right.$ and $\left.\tau_{2} \neq 0\right)$, by contrast, a change in the tax 
rate does not affect the domestic capital stock, but gives rise to a large deviation from the initial allocation of resources if the intertemporal substitution elasticity is large. An increase in the tax rate decreases the rate of return on savings. With a positive interest elasticity of savings, domestic residents borrow from abroad, thus reducng the second-period total tax bill. The response is larger, the larger the elasticity of intertemporal substitution in consumption. Therefore, a regime of uniform taxation should be preferable if domestic and foreign investment opportunities are similar, so that the interest elasticity of domestic investment is large, while the interest elasticity of savings is relatively small.

Since closed-form solutions to (12) and (13) cannot be obtained, I perform numerical simulations by assuming the following funactional forms for $\mathrm{U}$ and $\mathrm{f}$ :

$$
\begin{aligned}
& \mathrm{U}\left(\mathrm{C}_{1}, \mathrm{C}_{2}\right)=\left[\mathrm{C}_{1}^{1-\theta}+\mathrm{C}_{2}^{1-\theta} /(1+\delta)\right] /(1-\theta) \\
& \mathrm{f}\left(\mathrm{K}_{2}\right)=(1 / \alpha) \mathrm{K}_{2}^{\alpha}
\end{aligned}
$$

Under these assumptions, the elasticity of intertemporal substitution and the elasticity of returns to scale are constant, and equal to $1 / \theta$ and $\alpha$, respectively. In the simulations, $\mathrm{K}=1, \mathrm{r}^{*}=0.3$, and $\delta=0.25$. I study the effects of varying $\alpha$ and $\theta$ by computing the welfare loss of tax evasion for $G$ equal to 10,20 and 30 percent of first-period GNP. The welfare loss is the difference of $U\left(C_{1}, C_{2}\right)$ under uniform taxation and $U\left(C_{1}, C_{2}\right)$ with tax evasion, scaled by the marginal utility of first-period consumption (in the uniform taxation regime), and divided by first-period GNP.

In the top pane1, with $\alpha=0.4, \theta=4$ and $G=30$ percent of GNP, international 
tax evasion makes second-period GDP fall by roughly 10 percent, and gives rise to a loss equivalent to 1.2 percent of GNP. In the second panel I double the elasticity of intertemporal substitution in consumption, with the result that the welfare loss of $\operatorname{tax}$ evasion at $G=30$ percent of GNP is roughly halved. The two bottom panels in the table show the cases where domestic investment and production are almost unaffected by tax evasion and changes in taxes, because $\alpha$ is very small. In these cases tax evasion is welfare-superior to a regime of uniform taxation, especially when the intertemporal substitution elasticity equals $2(\theta=0.5)$, as in the bottom panel of the table. 10

10 Clearly, these simulations give more than a fair chance to tax evasion: the welfare cost of tax evasion should be computed relative the the solution of the optimal-tax problem outlined above, where both domestic-investment income and savings are taxed, i.e. both $\tau_{1}$ and $\tau_{2}$ are different from zero. 
4. The Inconsistency of Optimal Plans: Capital Levies and Capital Flight

In this section I make the tax rate endogenous, and discuss optimal fiscal policies. The government maximizes the representative individual's utility function, taking the optimal responses to taxation as given. As Kydland and Prescott [1980] and Fischer [1980] show, in this type of problem the optimal plans of the government are in general reneged as time goes by, since the exante price elasticity of the demand for capital goods differs from the ex-post elasticity. 11

What are the government's incentives to impose a capital levy and their effects on investors' behavior? I consider here the case where foreign assets are not taxable. The government's problem at time 1 is:

$$
\begin{array}{ll}
\operatorname{MAX} & \mathrm{W}\left(1+\mathrm{r}^{*}, \mathrm{Y}+\mathrm{K}\right)+\mathrm{v}(\mathrm{G}) \\
\text { s.t. } & \tau \mathrm{f}\left(\mathrm{K}_{2}\right)=\mathrm{G} \\
\mathrm{f}^{\prime}\left(\mathrm{K}_{2}\right)=\left(1+\mathrm{r}^{*}\right) /(1-\tau) \\
\mathrm{Y}=\mathrm{f}\left(\mathrm{K}_{2}\right)(1-\tau) /\left(1+\mathrm{r}^{*}\right)-\mathrm{K}_{2}
\end{array}
$$

the first-order conditions are:

$$
v^{\prime}(G)\left[1-\frac{f^{\prime}\left(K_{2}\right)}{f\left(K_{2}\right)} \frac{f^{\prime}\left(K_{2}\right)}{\left|f^{\prime \prime}\left(K_{2}\right)\right|} \frac{\tau}{1-\tau}\right]=\frac{W_{2}}{1+r^{*}}
$$

and equations (16), (4) and (17). The solution of the problem yields a value of $\tau$ that investors would use in their portfolio and savings decisions. At time 2

11 This problem is also disussed by Krugman [1987]. 
the government might want to renege on the announced tax rate. The problem at time 2 is:

$$
\begin{array}{ll}
\operatorname{MAX} U\left(C_{1}, C_{2}\right)+v(G) \\
\text { s.t. } C_{1}=K-A-K_{2} \\
C_{2}=A\left(1+r^{*}\right)+(1-\tau) f\left(K_{2}\right) \\
\tau f\left(K_{2}\right)=G \\
A, K_{2} \text { given }
\end{array}
$$

Since both $A$ and $K_{2}$ are given at time $2, C_{1}$ and $f\left(K_{2}\right)$ are given as well. Therefore, the first order conditions are:

$$
v^{\prime}(G)=\partial U / \partial C_{2}
$$

and equations (2), (3) and (16). (18) and (19) are unlikely to give rise to the same value of $\tau$. In the first period, the marginal government revenue from an increase in taxes--the second term on the left-hand side of (18)--times the marginal utility of government spending, has to equal the welfare cost of the tax distortion. In the second period, by contrast, the tax rate is such that the marginal utility of consumption is equal to the marginal utility of government spending.

Are the optimal ex-post taxes higher than ex-ante? The right-hand side of equation (18) equals $\mathrm{U}_{1} /\left(1+\mathrm{r}^{*}\right)$, since the derivative of the indirect utility function with respect to the present discounted value of available resources equals the Lagrange multiplier associated with the present-value budget 
constraint, and in turn, the marginal utility of period-one consumption. Therefore, given the consumption Euler equation (5), the right-hand side expressions in equations (18) and (19) are identical. Thus, a comparison of the left-hand sides of the two equations shows that ex-post government spending and taxes are always grater than ex-ante, if the marginal utility of government expenditure is decreasing.

Equations (18) and (19) also reveal that the government's incentive to raise higher taxes ex-post is stronger, the larger the response of international capital flows to future taxes, i.e. the more "similar" the domestic and foreign investment technologies: in this case the marginal tax revenue term in equation (18) is relatively small, thus driving a larger wedge between the ex-ante and ex-post marginal utility of government spending.

By a similar argument it is possible to show that, in the uniform taxation case, the government's incentives to raise higher taxes ex-post are positively related to the response of the current account to the savings tax rate: the higher the intertemporal elasticity of substitution the larger the difference between ex-post and ex-ante taxes.

Historically, examples of extraordinary taxation, like capital levies, debt repudiation, or exchange-rate "maxi" devaluations, are numerous. For this reason, and since the "fooling" equilibrium just described is unlikely to be self-replicating, it is plausible to study equilibria where the public anticipates the government's actions. Define a discretionary equilibrium as one where the the public perfectly anticipates future taxes, and the government has 
no incentives to renege on previous committments. ${ }^{12}$ In the government's problem at time 2 , the values of $C_{1}, A$, and $K_{2}$--that the government takes as given--are functions of taxes expected at time 1 . To make sure that the government will have no incentives to change the announced tax rate, the public has to choose $A$, $\mathrm{C}_{1}$, and $\mathrm{K}_{2}$ conditional on a value of $\tau$ consistent with the solution of the problem (1)-(3) and (16) above. Since ex-post taxes are always greater than their ex-ante optimal values, the discretionary equilibrium is characterized by "over-accumulation" of foreign assets. ${ }^{13}$ The accumulation of foreign assets in the discretionary equilibrium is larger, the more similar are the domestic and foreign investment technologies. Therefore, the arguments for preventing international capital flows for tax evasion are the same even when the endogeneity of government spending, and the effects of dynamic inconsistency, are explicitly accounted for: ${ }^{14}$ if the interest elasticity of domestic investment is large relative to the interest elasticity of savings, tax evasion lowers national welfare relative to a regime where domestic and foreign investment income are taxed at the same rate.

12 See Fischer [1986] for the a complete discussion of the welfare ranking of "first best," "time inconsistent" and "discretionary" equilibria.

13 An interesting historical example of this phenomenon is provided by the Italian experience in 1919. A capital levy was passed by the Italian government in November, and was publicly debated since the beginning of the year. The dollar price of liras in New York fell by 528 from December 1918 to December 1919, and many contemporary observers argued that capital flight for fear of the capital levy reached serious proportions in that year. See Giovannini [1987].

14 Since the logical structure of the proof of this proposition--as well as its intuition--are clearly the same as in section 3 , I nit it for brevity's sake. 
Table 2 illustrates these arguments, by reporting simulations of the full time-consistent discretionary equilibrium, assuming $v(G)=G^{\left(1-\theta_{1}\right)} /\left(1-\theta_{1}\right)$, and $\theta_{1}=1.5$. When $\alpha=0.4$, the public's anticipations of future confiscatory taxes much worsens the production distortions in the presence of tax evasion: output falls 25 percent below the first-best optimum of 210 . Similarly, when $\alpha=0.2$ and $\theta=2$, the relative ranking of the two regimes is sharply reversed. 15

\section{Concluding Remarks}

This paper has studied the simple analytics of tax evasion through international capital flows. The main result is that the welfare costs of international capital outflows to evade domestic taxes are larger, the larger the interest elasticity of domestic investment, relative to the interest elasticity of savings. Thus the relative importance of portfolio substituion and intertemporal substitution provide a simple criterion to evaluate the welfare effects of international tax evasion from an individual country's

15 This result stresses the large costs of savings taxation, rather than the superiority of tax evasion, with high intertemporal substitution, and low interest-rate elasticity of domestic investment. Tax evasion is of course still inferior to the regime where both domestic investment income and savings are taxed at differential rates. See footnote 10 above. 
perspective: ${ }^{16}$ this general criterion should not be overturned in more complicated models that account for uncertainty, many assets, a much richer menu of taxes, including taxes on labor income, and differential tax schedules on the various capital assets.

The analysis of this paper has Implications for the desirability of "capital controls." Capital controls decrease welfare in economies free of distortions, ${ }^{17}$ but can be welfare-improving when some distortions are unavoidable. Empirically, taxes are one of the most important distortions that cannot be eliminated. ${ }^{18}$ This paper suggests that the application of the "public finance" approach to normative questions like the optimal design of "controls" or taxation of international capital flows might prove fruitful.

16 Taking the rest of the world as exogenously given.

17 The effects of capital controls on equilibrium prices and quantities in an open economy are studied by Greenwood and Kimbrough [1984, 1985], Adams and Greenwood [1985], and van Wijnbergen [1985].

18 See Atkinson and Stiglitz [1980] for a review of the arguments demonstrating the impossibility of achieving lump-sum taxation. 
Appendix:

Quantitative Capital Controls Can Achieve the Uniform Taxation Solution

A regime of uniform taxation like the one described in section 2 might be difficult to achieve, since, for many governments, monitoring international trade in assets and evaluating foreign assets holdings of domestic residents is too costly. Traditionally, outright prohibitions of purchases of foreign assets are a frequently-used form of capital controls. Below I show that

appropriately-set quantitative controls achieve the same allocation of resources as a regime of uniform taxation. Consider the following problem:

$$
\begin{array}{ll}
\text { MAX } & U\left(C_{1}, C_{2}\right)+v(G) \\
\text { s.t. } & K_{2}+C_{1}+A=K \\
& C_{2}=A\left(1+r^{*}\right)+f\left(K_{2}\right)(1-\tau) \\
& A \leq \bar{A}
\end{array}
$$

Equation (a4) represents the quantitative controls on purchases of foreign assets. The first-order conditions for the problem (a1)-(a3) plus (a4) are:

$$
\begin{aligned}
& \mathrm{U}_{1}\left(\mathrm{C}_{1}, \mathrm{C}_{2}\right)=\mathrm{U}_{2}\left(\mathrm{C}_{1}, \mathrm{C}_{2}\right) \mathrm{f}^{\prime}\left(\mathrm{K}_{2}\right)(1-\tau) \\
& \mathrm{U}_{1}\left(\mathrm{C}_{1}, \mathrm{C}_{2}\right)=\mathrm{U}_{2}\left(\mathrm{C}_{1}, \mathrm{C}_{2}\right)\left(1+\mathrm{r}^{*}\right)-\mu
\end{aligned}
$$

and the intertemporal budget constraint (2)-(3), together with the "complementary slackness" condition: 


$$
\mu(\overline{\mathrm{A}}-\mathrm{A})=0
$$

In this problem, $\bar{A}$ can in fact be set at a level such that distortions on the production side of the economy are avoided. Let $\tau \mathrm{f}^{\prime}\left(\mathrm{K}_{2}\right) \mathrm{U}_{2}\left(\mathrm{C}_{1}, \mathrm{C}_{2}\right)=\mu$ : from equations (a5) and (a6), it follows that $f^{\prime}\left(k_{2}\right)=1+r^{*}$, as in equation ( $4^{\prime}$ ) in section 2 , and $\mu=\tau\left(1+r^{*}\right) U_{2}\left(C_{1}, C_{2}\right)$. Substituting into equation (a6) yields equation ( $\left.5^{\prime}\right)$ of section 2 , the other first-order condition from the uniform taxation problem. Solution of $\left(4^{\prime}\right)-\left(5^{\prime}\right)$ and the two budget constraints (a2)(a3) produces the values for consumption, savings, and foreign asset accumulation that are obtained in the uniform-taxation problem. Furthermore, given the value of $\mu$, auctioning the rights to purchase foreign assets generates the same revenue as in the case where foreign assets' income is taxed. Therefore, even when foreign assets' income cannot be taxed, appropriately-set quantitative restrictions can achieve an allocation of resources identical to that obtainable with a system of uniform taxation. 


\section{$\underline{\text { References }}$}

Adams, C., and J. Greenwood, "Dual Exchange Rate Systems and Capital Controls: An Investigation," Journal of International Economics, 1985.

Aizenman, J., "On the Complementarity of Commercial Policy, Capital Controls and Inflation Tax," NBER Working Paper n. 1583, March 1985.

Atkinson, A.B., and J.E. Stiglitz, Lectures on Public Economics, New York: McGraw Hill, 1980.

Bhagwati, J.N., Anatomy and Consequences of Exchange Control Regimes, NBER Conference Series on Foreign Trade Regimes and Economic Development, New York: Ballinger, 1978.

Diamond, P.A., "National Debt in a Neoclassical Growth Model," American Economic Review, 55, 1965, pp. 1126-1150

Diamond, P.A., "Incidence of an Interest Income Tax," Journal of Economic Theory, 2, 1970, pp. 211-224.

Dornbusch, R., "Impacts on Debtor Countries of World Economic Conditions," Forthcoming in External Debt. Investment and Growth in Latin America Washington, D.C.: IMF, 1987.

Findlay, C.C., "Optimal Taxation of International Income Flows," The Economic Record, vo1. 62, June 1986, pp. 208-214.

Fischer, S., "Dynamic Inconsistency, Cooperation, and the Benevolent Dissembling Government," Journal of Economic Dynamics and Control 2, 1980 , pp. $93-107$.

Fischer, S., "Time Consistent Monetary and Fiscal Policies: A Survey," mimeo, Massachusetts Institute of Technology, January 1986.

Frenkel, J.A., and A. Razin, "International Effects of Tax Reforms," mimeo, International Monetary Fund, August 1987.

Giovannini, A., "Capital Controls and Public Finance: The Italian Experience," manuscript, August 1987, forthcoming in High Public Debt: The Experience in Italy, ed. by L. Spaventa, Cambridge: Cambridge University Press.

Gordon, R.H., and H.R. Varian, "Taxation of Asset Income in the Presence of a World Securities Market," NBER Working Paper n. 1994, August 1986. 
Greenwood, J., and K.P. Kimbrough, "An Investigation in the Theory of Foreign Exchange Controls," mimeo, University of Western Ontario, August 1984 .

Greenwood, J. and K.P. Kimbrough, "Capital Controls and Fiscal Policy in the World Economy," Canadian Journal of Economics, 1985, pp. 743-765.

Horst, T., "A Note on the Optimal Taxation of International Investment Income," Quarterly Journal of Economics, 44, 1980, pp. 793-8.

Jones, R.W., "International Capital Movements and the Theory of Tariffs and Trade," Quarterly Journal of Economics, 81, February 1967, pp. 1-38.

Kemp, M.C., "The Gain from International Trade and Investment: A Neo-HeckscherOhlin Approach," American Economic Review, 56, September 1966, pp. $788-809$.

Krugman, P., "Rationales for Capital Controls," paper presented at the Seminar on Exchange Controls, Bogota', June 1987.

Kydland, F.E. and E.C. Prescott, "Dynamic Optimal Taxation, Rational Expectations, and Control Theory," Journal of Economic Dynamics and Control, 2, 1980, pp.

Obstfeld, M., "Capital Mobility in the World Economy: Theory and Measurement," Carnegie-Rochester Conference Series on Public Policy, Volume 24, Spring 1986, pp. 55-104.

Obstfeld, M., "Discussion of 'Capital Controls and Public Finance,' by Alberto Giovannini," manuscript, August 1987, forthcoming in High Public Debt: The Experience in Italy, ed. by L. Spaventa, Cambridge: Cambridge University Press.

Poterba, J.M., "Tax Evasion and Capital Gains Taxation," American Economic Review Papers and Proceedings, May 1987, pp. 234-239.

Sandmo, A., "Optimal Taxation," Journal of Public Economics 6, 1976, pp. $37-54$.

Stockman, A.C., and A.D. Hernandez, "Exchange Controls, Capital Controls, and International Financial Markets," mimeo, University of Rochester, September 1985.

Tanzi, V., "Quantitative Characteristics of the Tax Systems of Developing Countries," mimeo, International Monetary Fund, November 1983.

Torne11, A., "Capital Controls, Welfare and Reputation," mimeo, Massachusetts Institute of Technology, November 1986.

van Wijnbergen, S., "Capital Controls and the Real Exchange Rate," mimeo, 
The World Bank, October 1985.

Velasco, A., "Time Inconsistency in an Open Economy: Lack of Credibility and the Usefulness of Capital Controls, " mimeo, Columbia University, March 1987.

Walter, I., "The Mechanism of Capital Flight," manuscript, NYU October 1986. 
Table 1:

Assessing the We1fare Cost of Tax Evasion through International Investment

G

$\tau \quad f\left(K_{2}\right)$

A

$\mathrm{U}(2)-\mathrm{U}(1)$

(1)

(2)

(1)

(2)

(1)

(2)

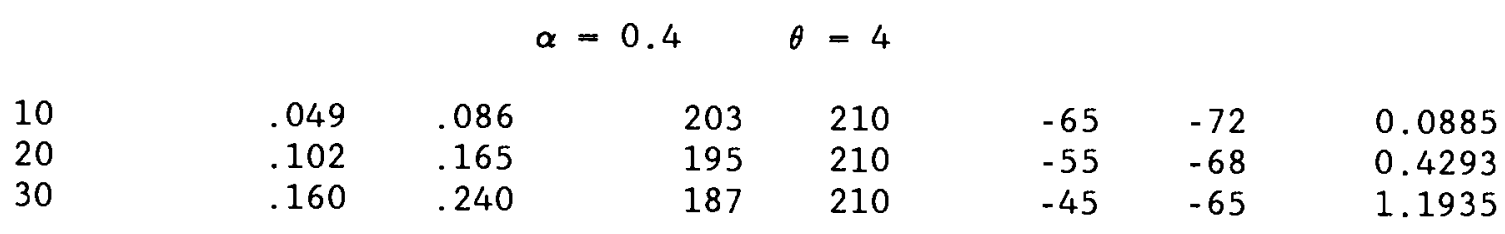

\begin{tabular}{|c|c|c|c|c|c|c|c|}
\hline 10 & .049 & .086 & 203 & 210 & -65 & -72 & 0.0379 \\
\hline 20 & .102 & .168 & 195 & 210 & -55 & -70 & 0.2129 \\
\hline 30 & .160 & .246 & 187 & 210 & -44 & -67 & 0.6681 \\
\hline
\end{tabular}

$\alpha=0.2 \quad \theta=4$

10

$.021 \quad .044$

$.043 \quad .087$

$466 \quad 468$

$463 \quad 468$

$\begin{array}{ll}-184 & -187\end{array}$

$-0.0033$

20
30

$.065 \quad .128$

460

468

$-177-183$

$-0.0104$

$-171-180$

$-0.0162$

$\alpha=0.2 \quad \theta=0.5$

10

.021

.044

$.043 \quad .092$

30

$.065 \quad .142$

$\begin{array}{ll}466 & 468 \\ 463 & 468 \\ 460 & 468\end{array}$

$\begin{array}{ll}-177 & -188 \\ -171 & -193 \\ -165 & -198\end{array}$

$-0.1794$

$-0.7991$

$-2.0303$

Notes: All variables, except tax rates, are expressed as percent of first-period GNP ( $=K)$. Columns ( 1 ) denote the regime where foreign assets' income is not taxed, columns (2) denote the regime of uniform taxation. $U(2)-U(1)$ is the difference between $U\left(c_{1}, c_{2}\right)$ in the regime of uniform taxation and $U\left(c_{1}, c_{2}\right)$ in the tax-evasion regime. This difference is also expressed as percent of firstperiod GNP. 
Table 2:

Assessing the Welfare Cost of Tax Evasion through International Investment The Case of Endogenous Taxes and Government Spending
$\alpha \quad \theta$
$\tau$
$f\left(K_{2}\right)$
A
$\mathrm{U}(2)-\mathrm{U}(1)$

(1)

(2)

(1)

(2)

(1)

(2)

$\begin{array}{rrrrrrrrr}0.4 & 4.0 & .381 & .411 & 152 & 210 & -9 & -55 & 10 \\ 0.2 & 0.5 & .277 & .644 & 432 & 468 & -107 & -271 & -80 .\end{array}$

Notes: All variables, except tax rates and taste and technology parameters, are expressed as percent of first-period GNP $(-K)$. Columns (1) denote the regime where foreign assets' income is not taxed, columns (2) denote the regime of uniform taxation. $U(2)-U(1)$ is the difference between $U\left(c_{1}, c_{2}\right)$ in the regime of uniform taxation and $U\left(c_{1}, c_{2}\right)$ in the tax-evasion regime. This difference is also expressed as percent of first-period GNP. 


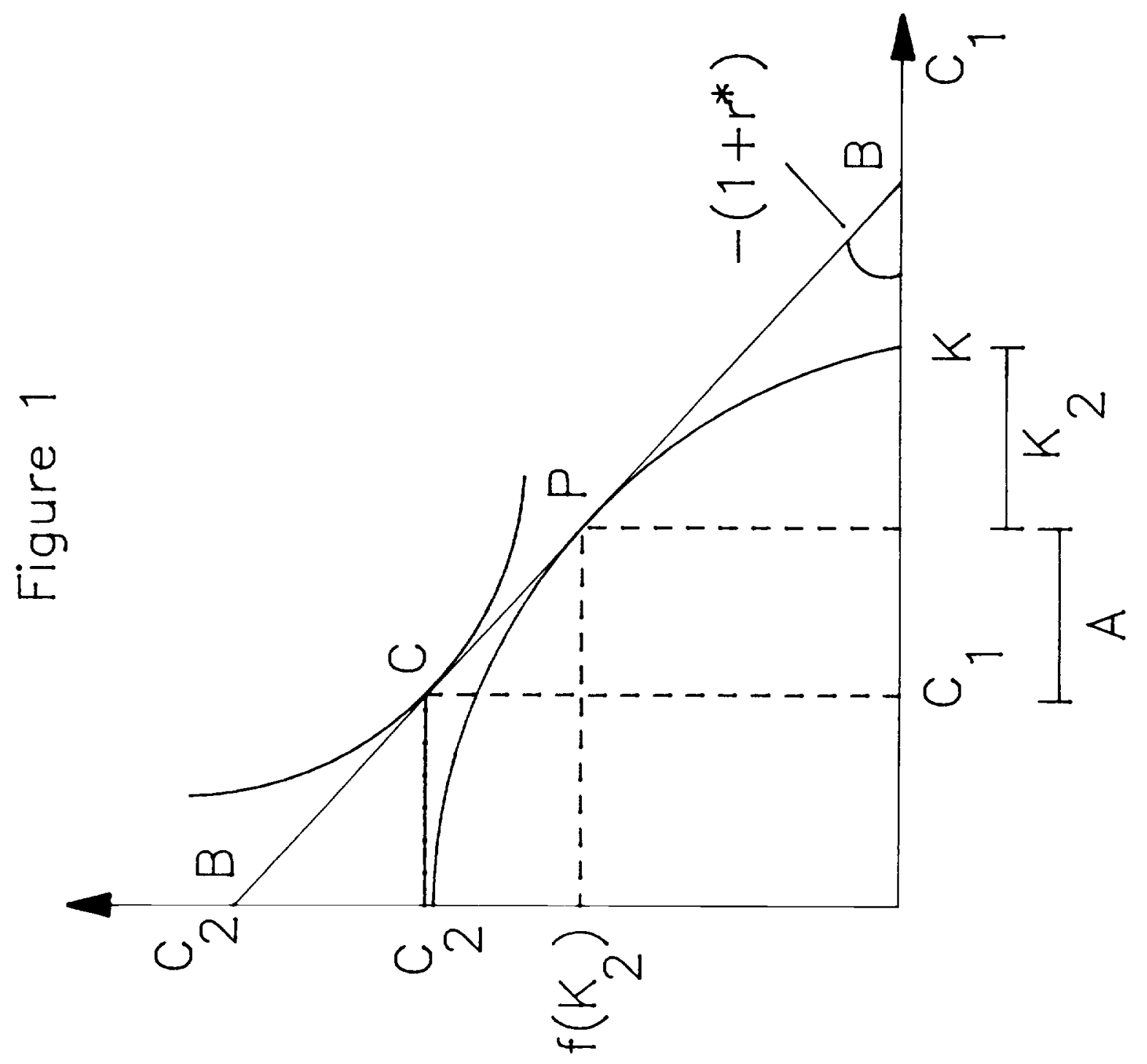




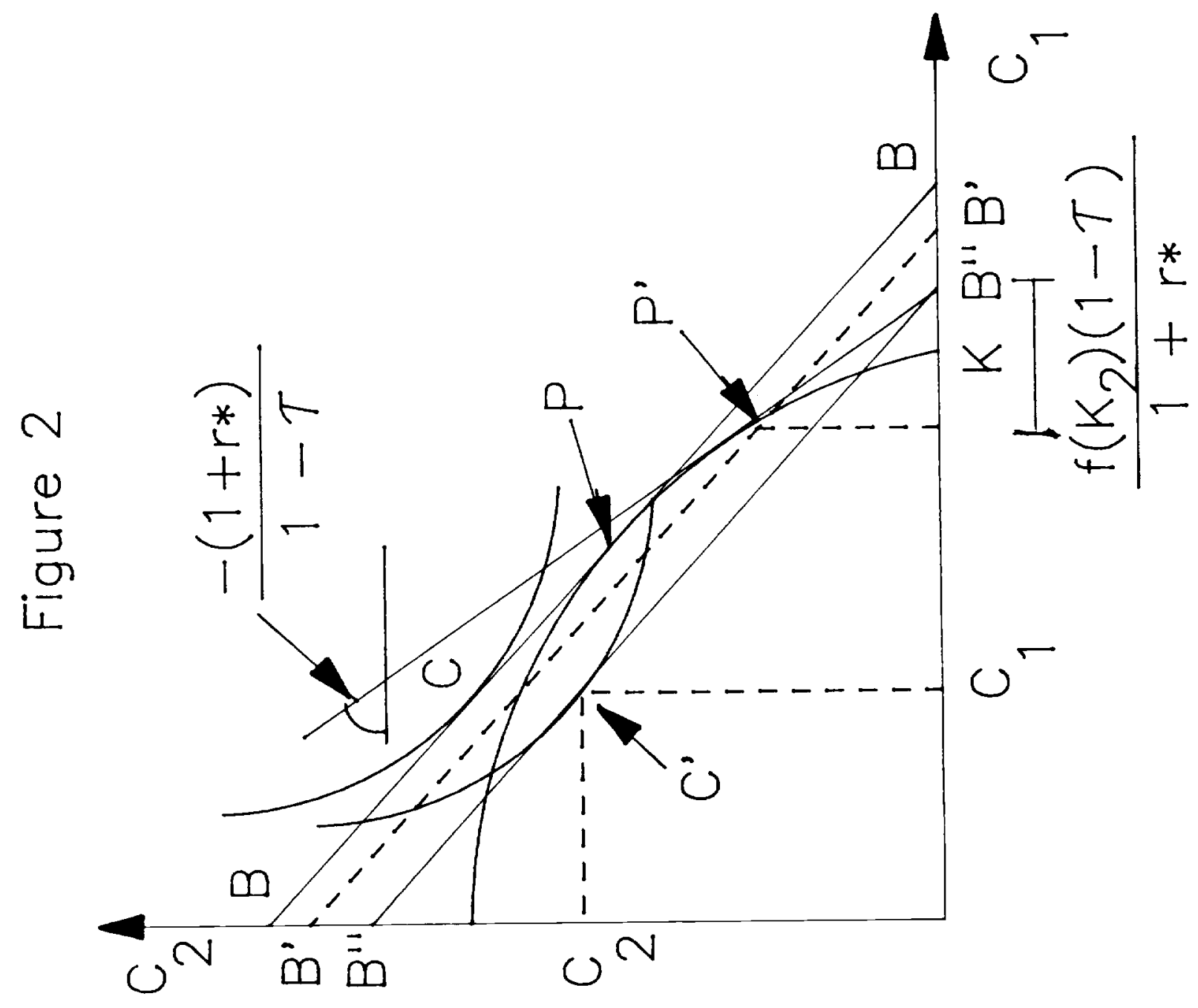




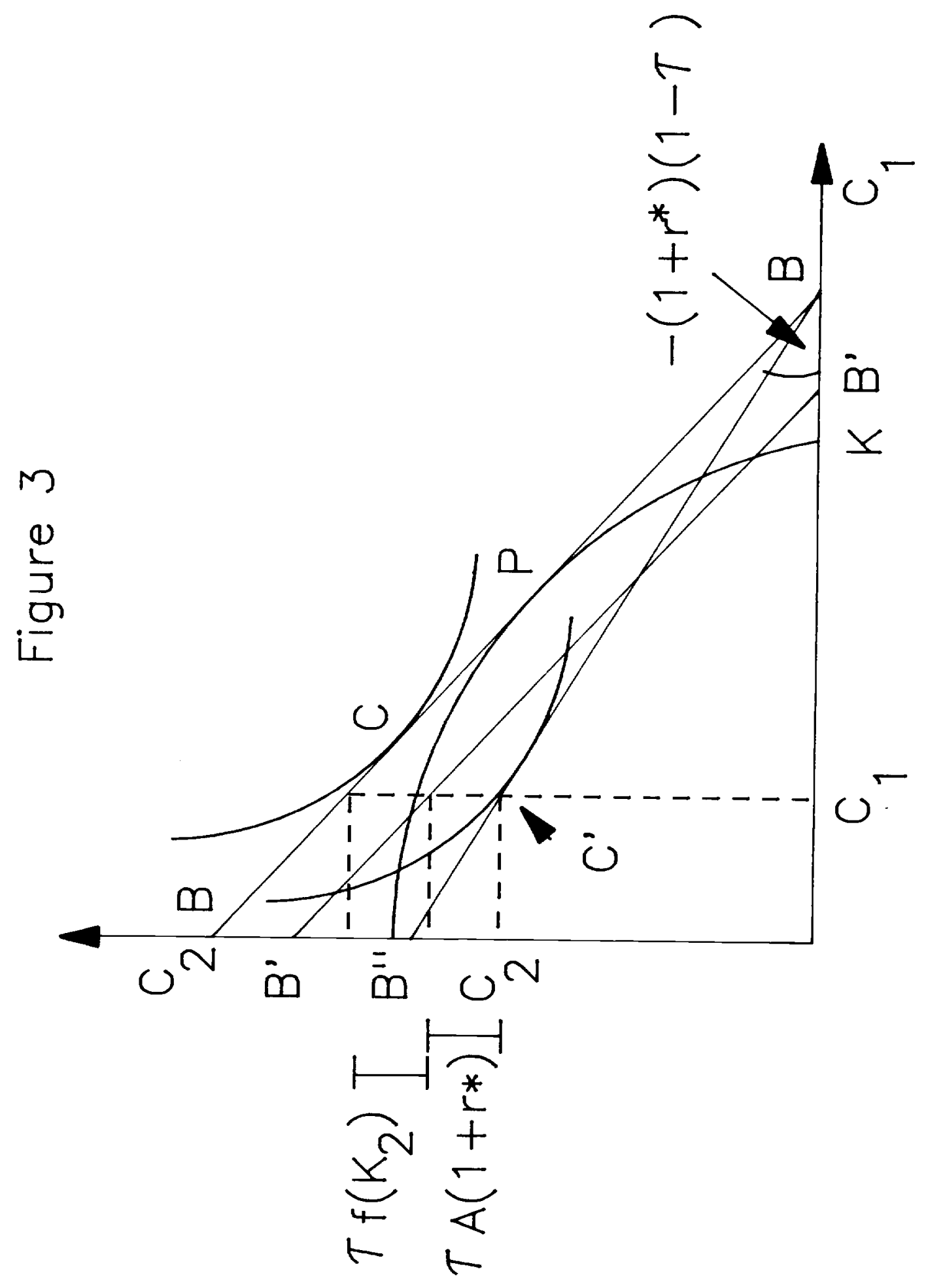

